\title{
Annual Report of the Chairman of the Anglo-Belarusian Society for 2015
}

\author{
BY \\ BRIAN BENNETT
}

2015 was a busy year for the Society. As well as the usual events of Mother Language Day, Kupallie, Kaliady and Batliejka, we organised an event in memory of Guy Picarda, a lecture by Dr Suša of the Belarusian National Library and presentations on Belarusian Nobel Prize winners. We supported a UCL conference on Grand Duchy micro-histories, the annual UCL Belarus lecture given by Per Rudling, and a book launch by Prof Arnold McMillin. We also said farewell to Fr Alexander and Count Ciechanowiecki both, in very different ways, staunch supporters of the Society. We were happy to see the Skaryna Library open to the public and construction begin on a new wooden church in the grounds of Marian House.

The year began as usual with the Annual General Meeting in Marian House on 24 January. We heard reports from Society post-holders, elected a new Council and reviewed the past year. Among the issues discussed were ways to increase the number of formal members of the Society so as to put the management and finances of the society on a sounder footing, but what emerged was a continuing preference for the present informal "pay-as-you-go" arrangements. The meeting agreed to protest the treatment of the Minsk bookshop Lohvinau and, in a joint action with the Skaryna Library in London, I duly wrote to the Belarusian Ambassador in London on 27 January to express the Society's deep concern at the heavy fine imposed on it.

Mother Language Day was held on 21 February in Marian House. Organised jointly with St Cyril's Sunday School, it was very well attended with a lot of audience participation and enjoyment.

UCL organised a conference on Grand Duchy of Lithuania micro histories 2021 March at SSEES. The Society's Patron was among those supporting it. The keynote speaker was Prof David Crick and papers were presented by historians from Belarus, Lithuania, Poland, the UK and the USA.

The well-attended Annual London Lecture on Belarusian Studies, organised by the UCL and the Ostrogorski Centre with the support of the Association of 
Belarusians in Great Britain, was given by Professor Per Anders Rudling at SEES on 25 March in cooperation with the Society and others.

Fr Alexander Nadson, head of the Belarusian Catholic Mission in the UK since 1959, passed away on 15 April and was laid to rest in the Islington and St Pancras Cemetery on 29 April after a Uniate service in St Mary's Roman Catholic Church just opposite. Amongst his many activities he had been Chairman and VicePresident of the Society and librarian of the Belarusian Library and Museum in London (the Skaryna Library). I represented the Society at his funeral, attended by many other members. He was a unique man with a unique history; we shall not see his like again.

On 13 June we held an event in memory of Guy Picarda, attended by his daughters Alice and Eloise. He had been Chairman of the Society and a major figure in the diaspora supporting Belarusian culture. Jim Dingley gave a talk on his life and the D L Singers sang Belarusian part songs from a collection Guy had brought together in 'Bielaruś Zalataja'.

We were pleased to see our friend and neighbour, the important Skaryna Library in Holden Road, open for visitors and students in June.

After Kupallie on DATE and the summer break we gathered at Marian House on 17 October for a lecture by Dr Alies Suša of the Belarusian National Library.

The Society was represented at the funeral on 16 November of Count Andrzej Ciechanowiecki, a major figure in the art world and patron of historical cultural restoration in Belarus. He was Patron of the Society.

On 21 November there was an event at Marian House consisting of presentations on Belarusian Nobel Prize winners and nominees, particularly Svetlana Alexievich who had just been awarded the Nobel Prize for Literature.

Prof Arnold McMillin, Vice President of the Society, launched his book 'Spring Shoots: Young Belarusian Poets in the Early Twenty-First Century' at UCL on 26 November.

The end of year Christmas festivities were marked at Marian House by a Nativity Play on 19 December organised by the Belarusian Sunday School led by headmistress Natallia Ramančuk, and Kaliady and Batliejka on 24 December. 